A $\mathrm{Cublications}$ Rec. Nat. Prod. 13:6 (2019) 506-511

records of natural

products

\title{
Cephalounei A, a New Cephalotaxus Alkaloid from the Powdered Stems of Cephalotaxus fortune Hook. f
}

\author{
Kang-Kang Mei $\oplus^{1}$, Guo-Kai Wang $\oplus^{2}$, He-Ping Cai ${ }^{1}$ and Zhi-Hong Luo ${ }^{1}{ }^{*}$ \\ ${ }^{I}$ Department of Pharmacy \& Anhui Provincial Children's Hospital, \\ Hefei, Anhui 230051, P. R. China \\ ${ }^{2}$ School of Pharmacy \& Anhui University of Chinese Medicine; Anhui Innovative Team from Colleges for \\ Scientific Research's Platform-The Innovative Team in Researching the Key Technologies concerning the \\ Integration of Processing Chinese Medicine Decoction Pieces in Producing Area, Hefei, Anhui 230012, P. \\ R. China
}

(Received February 23, 2019; Revised May 16, 2019; Accepted May 22, 2019)

\begin{abstract}
A new Cephalotaxus alkaloid, namely Cephalounei A (1), was isolated from the stems of Cephalotaxus fortune Hook. f. Their structures were elucidated by spectroscopic and mass-spectrometric analyses, including 1D-, 2DNMR and HRESIMS. The relative and absolute stereochemistry of $\mathbf{1}$ was determined by a combination of NOESY correlations and electronic circular dichroism (ECD) spectra, respectively. The cytotoxicity of all compounds were evaluated against five cancer cell lines.
\end{abstract}

Keywords: Cephalounei A; Cephalotaxus alkaloid; ECD. (C) 2019 ACG Publications. All rights reserved.

\section{Introduction}

Cephalotaxus alkaloids are a wide family of secondary metabolites isolated from Cephalotaxus genus trees, which possessed antileukemic activity and have been clinically utilized for the treatment of acute leukemia and lymphoma due to their diverse structure, especially the FDA-approved drug homoharringtonine (HHT) [1-2]. HHT and its derivatives had long side chains that were active group as different from cephalotaxines. To date, those of constituents were focused on phytochemistry, pharmacology, pharmacokinetics [3]. However, with respect to backbone skeletons of cephalotaxines were few reported [4]. Therefore, our chemical investigation on Cephalotaxus fortune Hook. f., with an endeavor to explore the instinct structure and bioactive derivatives of cephalotaxines alkaloids, a new biogenetic intermediates of Cephalotaxus alkaloid Cephalounei A, along with Cephalotaxine (2) [5], Cephalotaxinone (3) [6], Cephalotaxine acetate (4) [7], Demethylcephalotaxinone (5) [8], Drupacine (6) [9], 20, 21-Seco-3epischelhammericine (7) [10], Wilsonine (8) [11], were isolated from the powdered stems of $C$. fortune Hook. f.. Herein, their isolation and structural elucidation were descried.

\footnotetext{
* Corresponding author: E-Mail: ahsetyyyjk@163.com; Phone:086-551-62237597 Fax: 086-551-62237597
} 


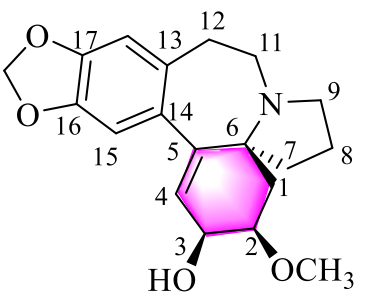

1<smiles>O=C1CC23CC(=O)C(O)=C2c2cc4c3cc2CCN2CCCC2(C1)OCO4</smiles>

5<smiles>COC1=C[C@]23CCCN2CCc2cc4c(cc2[C@@H]3[C@@H]1O)OCO4</smiles>

2



6<smiles>COC1=C[C@]23CCCN2CCc2cc4c(cc2[C@@H]3C1=O)OCO4</smiles>

3<smiles>COc1cc2c(cc1O)[C@@]13C[C@H](OC)CC=C1CCN3CCC2</smiles>

7<smiles>COC1=C[C@@]23CCCN2CCc2cc4c(cc2[C@@H]3[C@@H]1C(C)=O)OCO4</smiles>

4<smiles>COc1cc2c(cc1OC)[C@]13C[C@H](OC)C=CC1[C@@H]1CN(CCC2)[C@@H]13</smiles>

8

Figure 1. Structures of compounds 1-8

\section{Materials and Methods}

\subsection{General Experimental Procedures}

UV spectra were recorded on Shimadzu UV-2450 Spectrophotometer. IR spectra were determined by a Nicolet Impact-410 Spectrophotometer with $\mathrm{KBr}$ disks. Optical rotations were measured on a JASCOP1020 polarimeter. CD spectrum was obtained on a JASCO 810 spectropolarimeter. NMR spectra were carried out by a Bruker ACF-600 spectrometer operating at $600 \mathrm{MHz}$ for ${ }^{1} \mathrm{H} \mathrm{NMR}$ and $150 \mathrm{MHz}$ for ${ }^{13} \mathrm{C}$ NMR, with TMS as internal standard. The mass spectra of compounds were obtained on an ABI-Mariner Agilent 1100 MSD Trap (ESI-TOF-MS). For column chromatography, silica gel (100-200 mesh, 200-300 mesh) was obtained from Qingdao Marine Chemical Co. Ltd. and Sephadex LH-20 was purchased from Pharmacia Corporation.

\subsection{Plant Material}

The stems of $C$. fortune Hook. f. were collected from medicine market at Bo zhou Anhui Province, P. R. China, in Sep. 2017 and identified by Guo-kai Wang, Anhui University of Chinese Medicine. A voucher specimen (AAUF 20190516) has been deposited in the Herbarium, Anhui Agricultural university.

\subsection{Extraction and Isolation}

The air-dried and powdered stems of $C$. fortune Hook. f ( $5 \mathrm{~kg}$ ) was extracted with $95 \%$ alcohol at room temperature three times $(3 \times 20 \mathrm{~L})$. The extract was dissolved in $5 \% \mathrm{H}_{2} \mathrm{SO}_{4}$ solution $(\mathrm{v} / \mathrm{v})$ to $\mathrm{pH} 2-3$, basified with $10 \%$ ammonia solution $(\mathrm{v} / \mathrm{v})$ to $\mathrm{pH} 9$, and partitioned with EtOAc $(3 \times 1 \mathrm{~L})$ to afford the crude alkaloids $(20 \mathrm{~g})$. The crude alkaloids were subjected to column chromatography over silica gel eluted by $\mathrm{CH}_{2} \mathrm{Cl}_{2}-\mathrm{MeOH}$ (from 1:0 to 1:1) to yield three fraction A-C. Fraction A (3.6 g) was subjected to $\mathrm{C}_{18}$ MPLC with $\mathrm{MeOH}-\mathrm{H}_{2} \mathrm{O}(40: 60$ to $100: 0, \mathrm{~V} / \mathrm{V})$ as the eluent to obtain three subfractions (A1-A2). A1 was repurified on a silica gel column eluted with petroleum ether-acetone (5:1) to afford compound 5 (37 $\mathrm{mg}$ ). compound $2(150 \mathrm{mg})$ was crystallized from A2. Fraction B $(4.5 \mathrm{~g})$ was subjected to a silica gel column using gradient mixtures of dichloromethane and methanol to yield three subfractions (B1-B3). B1 (1.4 g) was further separated by Sephadex LH-20 chromatography eluting with $\mathrm{CH}_{2} \mathrm{Cl}_{2}-\mathrm{MeOH}(1: 1)$ and then separated 
on a preparative $\mathrm{C}_{18}$ column with a gradient $\mathrm{MeOH}-\mathrm{H}_{2} \mathrm{O}(50: 50$ to $40: 60$, v/v) to give $\mathbf{1}(5.4 \mathrm{mg})$ and 3 (7.8 $\mathrm{mg})$. B2 (2.7 g) was separated on MPLC with a gradient of $\mathrm{MeOH}-\mathrm{H}_{2} \mathrm{O}$ (30:70 to 80:20, v/v) and was applied to Sephadex LH-20 (MeOH) to give $6(4.4 \mathrm{mg})$ and $\mathbf{8}(10.2 \mathrm{mg})$. Fraction C (7.2 g) was subjected to silica gel CC using dichloromethane /acetone (10:1-1:1, gradient system) as mobile phases to afford two Fractions $\mathrm{C} 1-\mathrm{C} 2 . \mathrm{C} 2(2.5 \mathrm{~g})$ was applied to a $\mathrm{C}_{18} \mathrm{MPLC}$ with a gradient of $\mathrm{MeOH}-\mathrm{H}_{2} \mathrm{O}$ (10:90 to 50:50, $\mathrm{v} / \mathrm{v})$ and separated on a preparative $\mathrm{C}_{18}$ column with a gradient $\mathrm{MeOH}-\mathrm{H}_{2} \mathrm{O}(45: 55$ to $65: 35$, v/v) to give 4 $(9.1 \mathrm{mg})$ and $7(3.9 \mathrm{mg})$.

\subsection{Spectroscopic Data}

Cephalounei A (1): colorless amorphous solid. $[\alpha]_{D}^{21.6}=-2.87(C 0.0036, \mathrm{MeOH}) . \mathrm{IR} v_{\max }(\mathrm{KBr}): 3442$, 2931, 1484, 1223, $1035 \mathrm{~cm}^{-1}$. UV (MeOH) $\lambda_{\max }(\log \varepsilon): 294$ (2.75), 247 (2.84), 206 (3.56). ${ }^{1} \mathrm{H}(600 \mathrm{MHz}$, $\mathrm{CD}_{3} \mathrm{OD}$ ) and ${ }^{13} \mathrm{C}$ NMR $\left(150 \mathrm{MHz}, \mathrm{CD}_{3} \mathrm{OD}\right.$ ): Table 1.HR-ESI-MS $\mathrm{m} / z$ : $[\mathrm{M}+\mathrm{H}]^{+} 330.1700$ (calcd for $\mathrm{C}_{19} \mathrm{H}_{23} \mathrm{NO}_{4} 330.1700$ ).
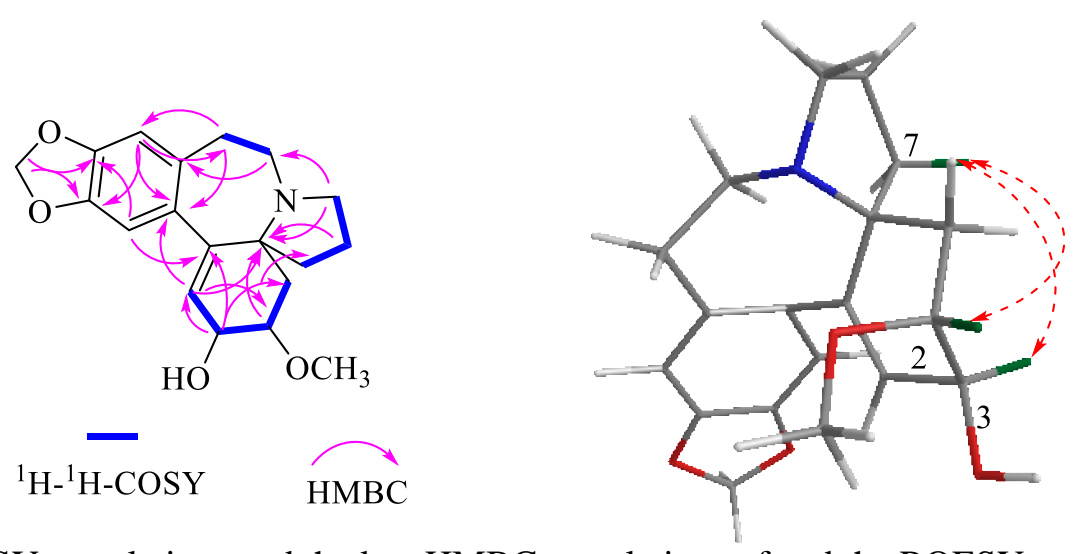

Figure 2. ${ }^{1} \mathrm{H}-{ }^{1} \mathrm{H}$ COSY correlations and the key HMBC correlations of and the ROESY correlations of compound 1

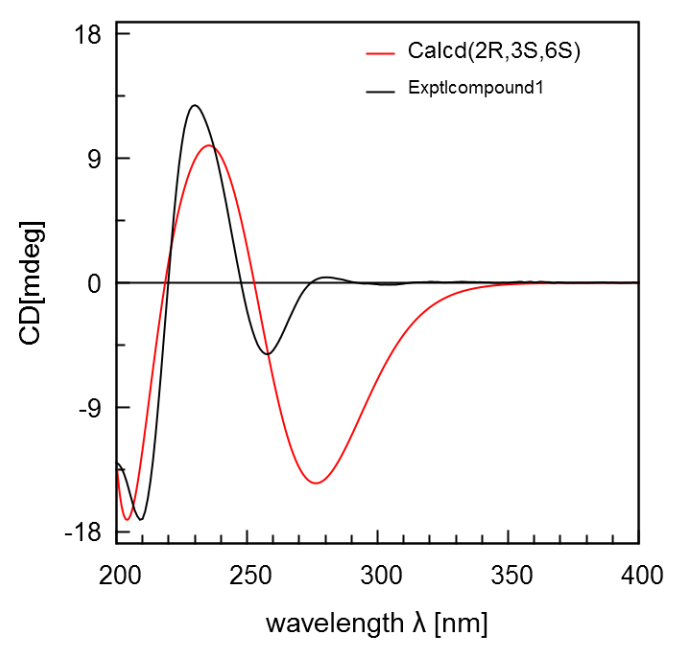

Figure 3. Experimental and calculated ECD spectra of 1(black line, experimentally recorded in methanol; red line, calculated for $2 R, 3 S, 6 S$ configuration in methanol) 


\section{Results and Discussion}

\subsection{Structure Elucidation}

Cephalounei A (1) was obtained as a colorless amorphous solid. Its molecular formula was deduced as $\mathrm{C}_{19} \mathrm{H}_{23} \mathrm{NO}_{4}$ by HRESIMS with $\mathrm{m} / z 330.1700[\mathrm{M}+\mathrm{H}]^{+}$(calcd for 330.1700), indicating the presence of 9 degrees of unsaturation in the molecule. The ${ }^{1} \mathrm{H}-{ }^{1} \mathrm{H}-\mathrm{NMR}$ spectrum for $\mathbf{1}$ exhibited characteristic signs of two unimodal and overlapped protons $\left(\delta_{\mathrm{H}} 6.57 \mathrm{~s}\right)$ in the benzene ring and a methylenedioxy group $\left(\delta_{\mathrm{H}} 5.89\right.$ and 5.88 AB, system, quasi doublet) similar to the literature values [12].

The ${ }^{13} \mathrm{C}-\mathrm{NMR}$ spectrum, with aid of DEPT and HSQC spectra, unlocked 19 carbon resonances attributable to a methoxy moiety, seven methylenes, five methines and six quaternary cartons (Table 1 and see supporting information). Among the unambiguous resonances, signals at the $\delta_{\mathrm{c}} 69.2,102.4,109.8,111.5$, 131.1, 134.2, 147.4, 148.6, combining with forgoing ${ }^{1} \mathrm{H}-{ }^{1} \mathrm{H}-\mathrm{NMR}$ data, was typical Cephalotaxus alkaloids and on the basis on above 1D NMR data, the original nucleus structure of 1 was similar to cephalolancine A [12], differing in that the location of double bond. The ${ }^{1}{ }^{H}-{ }^{1} \mathrm{H}$ COSY correlations of $\mathrm{H}-1 / \mathrm{H}-2 / \mathrm{H}-3 / \mathrm{H}-4$ indicated the one olefinic proton was displaced, rather than being all replaced. The deduction was confirmed by key correlations from H-4 to C-14/2/6, H-3 to C-1, H-2 to C-6, H-15 to C-5, H-8 to C-6 and H-7 to C-1 in the HMBC spectrum (Figure 2). In addition, dissection of the biosynthetic pathway for those type alkaloids, compound 1 derived from cephalolancine A through repeated oxidation, dehydration and reduction (Scheme 1). Therefore, the planar construction of Cephalounei A was established.

The relative configuration of $\mathbf{1}$ was determined on the basis of a ROESY experiment. The correlations of $\mathrm{H}-2 / \mathrm{H}-7 \mathrm{~b}$ and $\mathrm{H}-3 / \mathrm{H} 7 \mathrm{~b}$ suggested that $\mathrm{H}-2, \mathrm{H}-3$ and $\mathrm{H}-7 \mathrm{~b}$ were situated same side (Figure 2).

The absolute stereochemistry of $\mathbf{1}$ was elucidated by theoretical ECD calculation. The experimental and simulated spectra generated by time-dependent density functional theory (TDDFT), which performed at B3LYP/6-311g (2d, p) level in MeOH. As shown in Figure 3, the calculated ECD curve of 1 were in well agreement with the experimental one and their absolute configurations were assigned as $2 R, 3 S, 6 S$.

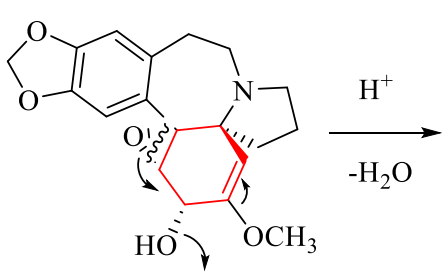

cephalolancine A
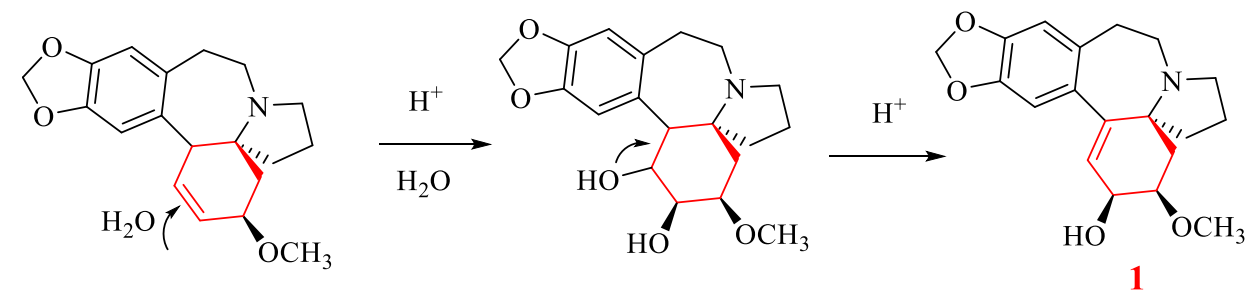

Scheme 1. Proposed biosynthetic pathway of $\mathbf{1}$

\subsection{Cytotoxicity Activity}

Compound 1-8 were evaluated in vitro for the cytotoxic activities against five cancer cell lines (including human myeloid leukemia HL-60, hepato cellular carcinoma SMMC-7721, lung cancer A549 cells, breast cancer MCF-7 and colon cancer SW480 cell lines). Unfortunately, none of selected compounds showed obviously inhibitory effect against five cancer cell lines $\left(\mathrm{IC}_{50}>40 \mu M\right)$. 
Table 1. ${ }^{1} \mathrm{H}$ and ${ }^{13} \mathrm{C}$ NMR spectroscopic data of compound $\mathbf{1}$

\begin{tabular}{|c|c|c|c|}
\hline Position & & $\mathbf{1}^{*}$ & \\
\hline & $\delta_{\mathrm{H}}(J$ in $\mathrm{Hz})$ & $\delta \mathrm{c}$ & HMBC correlations ( $\mathrm{H}$ to $\mathrm{C}$ ) \\
\hline \multirow[t]{2}{*}{1} & $1.98 \mathrm{dd}(8.45 .2)$ & 38.9 & $\mathrm{C}-2 / 3 / 5 / 6 / 7$ \\
\hline & 1.77 overlapped & & $\mathrm{C}-2 / 3 / 5 / 6 / 7$ \\
\hline 2 & $3.64 \mathrm{dt}(7.63 .3)$ & 79.0 & $\mathrm{C}-1 / 2-\mathrm{OCH}_{3} / 4 / 6$ \\
\hline $2-\mathrm{OCH}_{3}$ & $3.43 \mathrm{~s}$ & 57.2 & $\mathrm{C}-2$ \\
\hline 3 & $4.35 \mathrm{t}(4.0)$ & 66.4 & $\mathrm{C}-1 / 2 / 4 / 5 / 6$ \\
\hline 4 & $5.66 \mathrm{~d}(4.0)$ & 131.5 & C-2/3/5/6/14/15 \\
\hline 5 & & 147.5 & \\
\hline 6 & & 69.2 & \\
\hline \multirow[t]{2}{*}{7} & 1.79 overlapped & 39.2 & C- $8 / 9$ \\
\hline & $1.67 \mathrm{~m}$ & & C-5/6/8 \\
\hline 8 & $\begin{array}{c}1.76 \text { overlapped } \\
1.63 \mathrm{~m}\end{array}$ & 25.3 & $C-7 / 9$ \\
\hline \multirow[t]{2}{*}{9} & $2.85 \mathrm{~m}$ & 50.2 & C-6/7/8 \\
\hline & 2.79 overlapped & & C-6/7/8/11 \\
\hline \multirow[t]{2}{*}{11} & 3.40 ddd (15.0 5.72 .8 ) & 46.3 & C-6/9/12/13 \\
\hline & 2.95 ddd (15.0 5.72 .8$)$ & & C-6/12/13 \\
\hline \multirow[t]{2}{*}{12} & 3.17 ddd (15.0 5.7 2.8) & 33.0 & C-11/13/14/18 \\
\hline & $2.83 \mathrm{~m}$ & & C-11/13/14/18 \\
\hline 13 & & 131.1 & \\
\hline 14 & & 134.2 & \\
\hline 15 & $6.58 \mathrm{~s}$ & 111.5 & C-12/13/14/16/17 \\
\hline 16 & & 147.4 & \\
\hline 17 & & 148.6 & \\
\hline 18 & $6.57 \mathrm{~s}$ & 109.8 & C-13/14/16/17 \\
\hline \multirow{2}{*}{$\mathrm{OCH}_{2} \mathrm{O}$} & $5.89 \mathrm{~s}$ & 102.4 & C-16/17 \\
\hline & $5.88 \mathrm{~s}$ & & \\
\hline
\end{tabular}

${ }^{*}{ }^{1} \mathrm{H}\left(600 \mathrm{MHz}, \mathrm{CD}_{3} \mathrm{OD}\right)$ and ${ }^{13} \mathrm{C}$ NMR $\left(150 \mathrm{MHz}, \mathrm{CD}_{3} \mathrm{OD}\right)$

\section{Acknowledgments}

Computational resources used in this work were supported in the part by ScGrid, Chinese Academy of Sciences. This work was partially supported by the Foreign Visiting Programs of Anhui Province University for Distinguished Young Scholars (gxfx2017049) and Anhui Province College Excellent Young Talents .

\section{Supporting Information} natural-products

Supporting information accompanies this paper on http://www.acgpubs.org/journal/ records-of-

\section{ORCID}

Kangkang Mei: 0000-0002-1990-6182

Guokai Wang: 0000-0002-3924-6169

Heping Cai: 0000-0003-2175-7566

Zhihong Luo: 0000-0002-6384-0133

\section{References}

[1] A. Hajer and N. Bastien (2012). Natural Products from Cephalotaxus sp.: Chemical diversity and synthetic aspects, Nat. Prod. Rep. 29, 845-869.

[2] J. H. Siitonen, L. Yu, J. Danielsson, G. D. Gregorio and P. Somfai (2018). Formal synthesis of entcephalotaxine using a one-pot parham-aldol sequence, J. Org. Chem. 83, 11318-11322. 
[3] D. S. Moirangthem, J.C. Borah, S. Laishram, M.C. Kalita and N.C. Talukdar (2014). HPLC analysis of harringtonine and homoharringtonine in the needles of Cephalotaxus griffithii alkaloid fraction and cytotoxic activity on chronic myelogenous leukaemia K562 cell, Nat Prod Res. 28, 1503-1506.

[4] N. Ling. X. H. Zhong, J. Cai, M. F. Bao, B. J. Zhang, J. Wu and X. H. Cai (2016). Five new alkaloids from Cephalotaxus lanceolata and C. fortunei var. alpina, Nat. Prod. Bioprospect. 6:149-154.

[5] H. X. Li, Y. H. Wen, F. F. Wang, P. Wu and X.Y. We (2015). Cephalofortunone, a structurally unique cephalotaxus alkaloid from Cephalotaxus fortune Hook. f., Tetrahedron Lett. 42, 5735-5737.

[6] J. D. Eckelbarger, J. T. Wilmot and D. Y. Gin (2006). Strain-release rearrangement of N-Vinyl-2Arylaziridines. Total synthesis of the anti-Leukemia alkaloid (-)-Deoxyharringtonine, J. Am. Chem. Soc. 32, 10370-10371.

[7] Z. Xue, L.Z. Xu, D.H. Chen and L. Huang (1981). Studies on minor alkaloids of Cephalotaxus hainanensis Li., Yaoxue Хиеbao. 10, 752-756.

[8] L.W. Wang, H.J. Su, S.Z. Yang, S.J. Won and C.N. Lin (2004). New alkaloids and a tetraflavonoid from Cephalotaxus wilsoniana, J. Nat. Prod. 7, 1182-1185.

[9] Q. Liu, E. M. Ferreira and B. M. Stoltz (2007). Convergency and divergency as strategic elements in total synthesis: The total synthesis of $(-)$-Drupacine and the formal total synthesis of $( \pm)$-Cephalotaxine, $(-)$ Cephalotaxine, and (+)-Cephalotaxine, J. Org. Chem. 19, 7352-7358

[10] H. Morita, M. Arisaka, N. Yoshida and J. Kobayashi (2000). Cephalezomines A-F, Potent cytotoxic alkaloids from Cephalotaxus harringtonia var. Nana, Tetrahedron 19, 2929-2934.

[11] Z. H. Liu, Q. Z. Du, K. W. Wang, L. L. Xiu and G. L. Song (2009). Completed preparative separation of alkaloids from Cephaltaxus fortunine by step-pH-gradient high-speed counter-current chromatography, J. Chrom. A. 22, 4663-4667.

[12] L. Ni, J. Schinnerl, M. F. Bao, B. J. Zhang, J. Wu and X. H. Cai (2016). Two key biogenetic intermediates of cephalotaxus alkaloids from Cephalotaxus oliveri and C. Lanceolata, Tetrahedron Lett. 47, 5201-5204.

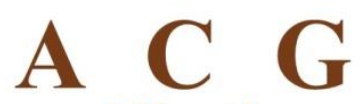

publications

(C) 2019 ACG Publications 